\title{
Healthy Nurses for a Quality Health Care Service: A Literature Review
}

\author{
Dodi Wijaya', Nyoman Anita Damayanti \\ ${ }^{1}$ Doctoral Program of Public Health, Faculty of Public Health, ${ }^{2}$ Faculty of Public Health, \\ Universitas Airlangga, Mulyorejo, Surabaya, Indonesia
}

\begin{abstract}
Healthy nurses are a key component when providing quality health care. This paper aims to review the factors that may relate to the physical and spiritual health status of nurses, and the extent to which health affects the work productivity of nurses which ultimately, has an impact on the quality of health services. We conducted a literature search via an online database and found 92 articles with keywords related to this topic. After the inclusion and exclusion criteria were applied, 15 articles were included in the analysis. Implementing a health promotion model is beneficial to encourage nurses practicing a healthy lifestyle behaviour and improve their health status. This includes creating a healthy work environment, physical activity, having regular meals as part of a balanced nutritional diet, having sufficient rest, and practising stress management.
\end{abstract}

Keywords: healthy nurses, quality health services, health promotion

\section{INTRODUCTION}

The nursing workforce contributes the largest portion to health professionals globally. The important role of nursing workforce in improving health outcomes has been widely recognised. ${ }^{1}$ According to the International Council of Nurses (ICN), the nursing workforce is an integral part of the health system, therefore maintaining a sufficient number of nurses is a prerequisite for quality of care. ${ }^{2}$ Nurses should actively focus on creating and maintaining a balance of physical, intellectual, emotional and social welfare, as well as professional and personal synergism in order to provide quality nursing care. ${ }^{3}$ However, the provision of quality nursing care has been challenged by the poor working environment, long working hours, workplace stress and unhealthy life style of nurses. ${ }^{4}$

\section{Corresponding Author:}

Dodi Wijaya

Doctoral Program of Public Health, Faculty of Public Health, Universitas Airlangga, Mulyorejo, Surabaya, Indonesia

Faculty of Nursing, University of Jember, Jember, East Java, Indonesia

Email: dodi.wijaya-2017@fkm.unair.ac.id
Nurses have voiced their frustration at the high demand of quality nursing care when there is a staff shortage. ${ }^{5}$ The workforce shortage including nursing is a common problem in Indonesian public health facilities. ${ }^{6}$ According to the Indonesian Ministry of Health $(\mathrm{MoH})$, as of December 2016, approximately 601,228 health workers including physicians, medical specialists, dentists, nurses, midwives, and pharmaceutical workers work in 15,263 health facilities throughout Indonesia. ${ }^{7}$ Although the nursing workforce is the largest proportion out of the health professionals (49\%), the current nursing ratio is 113.4 nurses per 100,000 population. ${ }^{7}$ The nursing workforce density is still far below the national target of 180 nurses per 100,000 population, set for $2019 .{ }^{8}$ Working in a facility with poor staffing could leave the nurses exhausted, which impacts on nursing quality. ${ }^{5}$

The quality of the nurse is determined by the nurse's health status as has an impact on the nurse's productivity when providing health services. Several factors influence the reduction of employee productivity, including education level, physical and spiritual health status, the work environment, leadership, motivation and the equipment utilised. ${ }^{9}$ Poor physical and mental health status, as well as poor working conditions, have been shown to reduce nursing productivity in previous 
studies. ${ }^{10,11}$ This study aims to review the factors that may relate to the physical and spiritual health status of nurses, that in turn affect their work and productivity which ultimately has an impact on the quality of the health services that they provide.

\section{METHOD}

We searched for articles on online databases including Science Direct, Google Scholar, Proquest Health and Medical Complete, Proquest Nursing and Allied Health Source, Proquest Psychology Journals and Proquest Science Journals. We used keywords such as healthy nurse, quality of nursing care, and nursing productivity. The search engines generated a total of 92 articles. The following inclusion criteria were used to select the articles:

- Articles published in the last 10 years

- The topics relevant to the health of nurses as a support system in the quality of health services.

- Articles published in English or Bahasa Indonesian

After applying the inclusion criteria, 45 articles were selected. However, after studying the content, only 15 articles with a more detail discussion about the healthy behaviour of nurses related to supporting the quality of the provided health services were included in this literature review.

\section{RESULTS}

Four studies focused on the health status of nurses in relation to their behaviour in the work place. Eleven studies were concerned with the demographic characteristics and self-perception that influence lifestyle behaviour.

Health Status: Henwood, Tuckett \& Turner (2012) conducted a cohort study involving 2,264 nurses in Australia and New Zealand in order to investigate the different effects from the physical activity of nurses in the workplace and their leisure time on their health status. Their study found that compared to nurses with normal working hours and leisure time, the nurses who worked longer with less leisure time were more likely to have a higher body mass index and took more days off due to sickness. They were also more likely to experience sleep problems, depression and anxiety. ${ }^{12}$
Schluter et al. (2011) described the demographics and health condition of 6,308 nurses and midwives in Australia and New Zealand. Their study revealed that approximately $30 \%$ of nurses and midwives had never had a health check-up within the last two years. The nurses and midwives also experienced sleep disorder (35.2\%), severe depression (22\%) and had upper back, neck and lower back pain $(26.3 \%){ }^{13}$

Similarly, a study among hospital staff in South Africa reported that about $73 \%$ of health workers were obese and half of them had never made effort to reduce their weight. No significant difference of body mass index was found between the medical and non-medical staff members. About one third of the participating health workers had obesity-related non-communicable diseases and stress. ${ }^{14}$

A qualitative study of hospital nurses in South Africa reported that night shift nurses complained about being overweight and contracting non-communicable diseases as their main health problems. The nurses also complained about work-related problems such as back pain, exposure to tuberculosis and a stressful work environment. Being too exhausted was the main reason of the nurses for being unable to prepare healthy food and do physical activity. ${ }^{15}$

Lifestyle behaviour: Three studies have explored the lifestyle behaviour of nurses using the Pender health promotion model. ${ }^{16-18}$ McElligott et al (2009) observed certain weaknesses in relation to managing stress and physical activity among nurses. They found no significant difference between units of care, and demographic characteristics in the nurse's lifestyle and behaviour. The health promotion scores were significantly higher among the critical-care nurses than the medical-surgical nurses. ${ }^{16}$ Al-Qahtani (2014) conducted a study in Saudi Arabia which found that the majority of nurses were non-Saudis (98\%) with approximately 5 to 10 years of working experience (38\%). In assessing the nurse's lifestyle, they found that spiritual needs had the highest average score, while physical activity had the lowest average score. ${ }^{17}$ Another study by Nahm et al (2012) found that despite being at a higher risk of health problems such as being overweight/obesity due to the working environment, this issue was rarely addressed by the nurses. ${ }^{18}$

A study by Zapka et al (2009) examined the lifestyle of hospital nurses and their bodyweight. They found that 
most of the nurses in their study were either overweight or obese, and did not apply weight management behavior. There was a significant relationship between demographic characteristics (age, gender, marital status, education, and history of hypertension), the selfperception of body weight and diet and physical activity behaviours. ${ }^{19}$

Two studies examined the relationship between the nurses' personal health practices and the perception of the self as a role model in health promotion. Hurley et al (2017), adopting the Miller and Dollard Social Cognitive theory, used the Self as a Role Model of Health Promotion (SARMHEP) questionnaire. Their study found a significant correlation between practicing a healthy lifestyle and the nurses' perception of self as the role model for health promotion. ${ }^{20}$ Another study by Bakhshi et al (2015) reported that almost half of the study subjects promoted physical activity in their clinical practice. Perceived health status, the length of their clinical practice experience, clinical specialisation, and actual body weight were significantly associated with physical activity practices. On the other hand, in another study, the nurses described the obstacles preventing them from doing physical activity such as time, cost, exhaustion, low self-efficacy, and a lack of social support. However, the performance level and absenteeism showed no significant difference between nurses who actively did sports and those who did not. ${ }^{21}$

A study by Blake \& Harrison (2013) explored the health behaviour of nurses and their attitude related to promoting health. Their study found that nurses with a normal body weight were more likely to achieve the recommended level of physical activity than the underweight or overweight nurses. Most of the respondents $(79.1 \%)$ confirmed that nurses should be a role model in relation to health behaviour. ${ }^{22}$ Similarly, another study also found a significant high score in the general perception of health among healthy nurses rather than unhealthy nurses. ${ }^{23}$

Malik, Blake, \& Batt (2015) conducted a study to compare between registered nurses $(\mathrm{RN})$ and pre-registered nurses (PRN) as health promoters in transforming their knowledge of healthy lifestyle into their attitude, in order to develop interventions for their patients. The RN group significantly had a healthier lifestyle than the PRN group. However, almost half of nurses in the both groups did not meet the recommended level of physical activity, while about two thirds did not meet the recommended daily consumption of fruit and vegetables. ${ }^{24}$

Hensel (2011) investigated the relationship between having a healthy lifestyle and self-concept among hospital nurses using the Nurse Self-Concept Questionnaire (NSCQ) and the Health Promoting Lifestyle Profile (HPLP II). The study found that each aspect of the nurse's self-concept was significantly related to the nurse's lifestyle. Communication and leadership were significantly associated with the nurses' health status. ${ }^{25}$

\section{DISCUSSION}

Provision of health care service has the ultimate goal of improving the health status of the population. Satisfactory health care is achieved by the interrelatedness of the fulfilment of community needs and expectations (consumer satisfaction), what should be effectively delivered by the service providers (provider satisfaction) and efficiently organised by the service institution (institutional satisfaction). ${ }^{26} \mathrm{~A}$ robust health care system require support from quality nursing care, which can only be delivered by healthy nurses. Healthy nurses represent a level of quality of nursing staff that can be measured in their physical, mental, social and spiritual abilities when providing quality health services.

From the studies reviewed, healthy nurses can be achieved by applying a holistic approach to health and organisational management. A holistic approach of the health promotion model for nurses can be used improve the healthy lifestyle behaviours. It also includes the establishment of a healthy work environment, opportunities to do sufficient physical activity, a regular and balanced diet, sufficient resting time, and stress management. A healthy work environment has a positive impacts on nurses such as increased work productivity, a lower rate of absenteeism, and improved organisational outcomes. ${ }^{10,12}$

During working hours, nurses carry out physical activities including visiting patients, lifting patients and performing general nursing care which is assumed to be equal to moderate physical activity for 30 minutes. ${ }^{12}$ However, the study results showed that the health outcome of nurses doing physical activity only during their working hours was worse compared to nurses who 
did physical activity during their leisure time. ${ }^{12}$ Some barriers for nurses to doing physical activity during their leisure time included a lack of time due to long working hours, and changes in their shifts. ${ }^{12,18}$ Nurses may also put in less effort to have or maintain the exercise habit. ${ }^{18}$ Poor eating habits among nurses in Saudi Arabia was related to being on the night shift rotation and facing high stress due to the high workload. ${ }^{27}$

Having a sleep disorder may affect the health of the nurses which results in increased medical errors during their working hours at the cost of the patient's safety as well as burnout. ${ }^{28}$ Nursing care requires a high quality of performance regardless of the long and irregular working hours involved, which causes an increased level of stress. ${ }^{13}$ High psychological demands, low decision authority, and low social support are the predictors of poor health among nurses working in hospitals. ${ }^{29}$ High workload and staff shortages were the factors related to psychological disorders which were represented by a high rate of absenteeism among nurses. ${ }^{30}$

\section{CONCLUSIONS}

Healthy nurses are crucial in increasing nursing care productivity in order to support a strong health care system. Promoting the health of nurses can be done by implementing a holistic approach to health and organizational management, including providing healthy work environment which enable nurses to adopt healthy lifestyle behavior. Nursing managers play a pivotal role to address these issues in the workplace.

In Indonesia, despite the long standing issue of staff shortage, adopting strategies related to a healthy work environment should be conducted by policy makers, hospital managers and nurse managers. A health promotion strategy should also be conducted in order to encourage the health behaviour of nurses, including doing physical activity, having regular meals with a balanced diet, having sufficient rest and practising stress management.

Ethical Clearance: Ethical approval was granted by the School of Public Health in Airlangga University, Surabaya.

Source of Funding: Self funding.

Conflict of Interest: Nil.

\section{REFERENCES}

1. World Health Organization. The world health report 2006: working together for health: World Health Organization. 2006.

2. ICN. Safe staffing key to quality health care Geneva: International Council of Nursing; 2013 [Available from: http://www.icn.ch/images/ stories/documents/news/press_releases/2013_ PR_13_Safe\%20staffing.pdf.

3. American Nurses Association. Healthy nurse, healthy nation. 2016.

4. Baer HJ, Glynn RJ, Hu FB, Hankinson SE, Willett WC, Colditz GA, et al. Risk factors for mortality in the nurses' health study: a competing risks analysis. American journal of epidemiology. 2010; 173(3):319-29.

5. Forster DA, McLachlan HL, Yelland J, Rayner J, Lumley J, Davey M-A. Staffing in postnatal units: is it adequate for the provision of quality care? Staff perspectives from a state-wide review of postnatal care in Victoria, Australia. BMC health services research. 2006; 6(1):83.

6. Kurniati A, Rosskam E, Afzal M, Suryowinoto T, Mukti A. Strengthening Indonesia's health workforce through partnerships. Public health. 2015; 129(9):1138-49.

7. MoH. Situasi Tenaga Keperawatan di Indonesia (Nursing workforce in Indonesia). In: Informasi PDd, editor. Jakarta: Kementerian Kesehatan RI; 2017.

8. Kemenkokesra. Keputusan Menteri Koordinator Bidang Kesejahteraan Rakyat Republik Indonesia Nomor 54 Tahun 2013 Tentang Rencana Pengembangan Tenaga Kesehatan Tahun 2011-2025 [Decree of the Coordinating Minister for People's Welfare of the Republic of Indonesia Number 54 Year 2013 About the Health Manpower Development Plan 2011-2025]. Jakarta: Kemenkokesra; 2013.

9. Hasibuan M. Organisasi dan Motivasi Dasar Peningkatan Produktifitas (Organization and the Basic Motivation to Increase Productivity). 6 ed. Jakarta: PT. Bumi Aksara; 2007.

10. Berger AM, Hobbs BB. Impact of shift work on the health and safety of nurses and patients. Clinical journal of oncology nursing. 2006; 10(4). 
11. Letvak S, Ruhm C, Lane S. The impact of nurses' health on productivity and quality of care. Journal of Nursing Administration. 2011; 41(4):162-7.

12. Henwood T, Tuckett A, Turner C. What makes a healthier nurse, workplace or leisure physical activity? Informed by the Australian and New Zealand e-Cohort Study. Journal of clinical nursing. 2012; 21(11-12):1746-54.

13. Schluter P, Turner C, Huntington A, Bain C, McClure R. Work/life balance and health: the Nurses and Midwives e-cohort study. International Nursing Review. 2011; 58(1):28-36.

14. Skaal L, Pengpid S. Obesity and health problems among South African healthcare workers: do healthcare workers take care of themselves? South African Family Practice. 2011; 53(6):563-7.

15. Phiri LP, Draper CE, Lambert EV, KolbeAlexander TL. Nurses' lifestyle behaviours, health priorities and barriers to living a healthy lifestyle: a qualitative descriptive study. $B M C$ nursing. 2014; 13(1):38.

16. McElligott D, Siemers S, Thomas L, Kohn N. Health promotion in nurses: is there a healthy nurse in the house? Appl Nurs Res. 2009; 22(3):211-5.

17. Al-Qahtani MF. Health-promoting lifestyle behaviours among nurses in private hospitals in Al-Khobar, Saudi Arabia. Journal of the Egyptian Public Health Association. 2015; 90(1):29-34.

18. Nahm E-S, Warren J, Zhu S, An M, Brown J. Nurses' self-care behaviours related to weight and stress. Nursing outlook. 2012; 60(5):e23-e31.

19. Zapka JM, Lemon SC, Magner RP, Hale J. Lifestyle behaviours and weight among hospitalbased nurses. J Nurs Manage. 2009; 17(7):853-60.

20. Hurley S, Edwards J, Cupp J, Phillips M. Nurses' perceptions of self as role models of health. Western J Nurs Res. 2017:0193945917701396.
21. Blake H, Malik S, Mo PK, Pisano C. 'Do as I say, but not as I do': Are next generation nurses role models for health? Perspectives in public health. 2011; 131(5):231-9.

22. Blake H, Harrison C. Health behaviours and attitudes towards being role models. British Journal of Nursing. 2013; 22(2):86-94.

23. Blake H, Mo PK, Lee S, Batt ME. Health in the NHS: lifestyle behaviours of hospital employees. Perspectives in Public Health. 2012; 132(5):213.

24. Malik S, Blake H, Batt M. How healthy are our nurses? New and registered nurses compared. British Journal of Nursing. 2011; 20(8):489-96.

25. Hensel D. Relationships among nurses' professional self-concept, health, and lifestyles. Western J Nurs Res. 2011; 33(1):45-62.

26. Djojosugito A. Kebijakan Pemerintah Dalam Pelayanan Kesehatan Menyongsong ASEAN Free Trade Area (AFTA) 2003. (The Indonesia Government policy in health care service to welcome AFTA 2003). 2001.

27. Almajwal AM. Stress, shift duty, and eating behavior among nurses in Central Saudi Arabia. Saudi medical journal. 2016; 37(2):191.

28. Dorrian J, Grant C, Banks S. An industry case study of 'stand-up'and 'sleepover' night shifts in disability support: Residential support worker perspectives. Applied ergonomics. 2017; 58:1108.

29. Pappas NA, Alamanos Y, Dimoliatis ID. Selfrated health, work characteristics and health related behaviours among nurses in Greece: a cross-sectional study. BMC nursing. 2005; 4(1):8.

30. Jinks AM, Lawson V, Daniels R. A survey of the health needs of hospital staff: implications for health care managers. J Nurs Manage. 2003; 11(5):343-50. 